\title{
SPATIO-TEMPORAL MODELLING OF THE DURATION OF THE COTTON CYCLE IN THE STATE OF GOIÁS, BRAZIL
}

\author{
JORGE C. DOS A. ANTONINI ${ }^{1}$, EUZEBIO M. DA SILVA ${ }^{2}$, NORI P. GRIEBELER ${ }^{3}$, \\ EDSON E. SANO ${ }^{4}$
}

\begin{abstract}
The objective of this work was to develop and validate a mathematical model to estimate the duration of cotton (Gossypium hirsutum L. r. latifolium hutch) cycle in the State of Goiás, Brazil, by applying the method of growing degree-days (GD), and considering, simultaneously, its time-space variation. The model was developed as a linear combination of elevation, latitude, longitude, and Fourier series of time variation. The model parameters were adjusted by using multiple-linear regression to the observed GD accumulated with air temperature in the range of $15^{\circ} \mathrm{C}$ to $40^{\circ} \mathrm{C}$. The minimum and maximum temperature records used to calculate the GD were obtained from 21 meteorological stations, considering data varying from 8 to 20 years of observation. The coefficient of determination, resulting from the comparison between the estimated and calculated GD along the year was 0.84 . Model validation was done by comparing estimated and measured crop cycle in the period from cotton germination to the stage when 90 percent of bolls were opened in commercial crop fields. Comparative results showed that the model performed very well, as indicated by the Pearson correlation coefficient of 0.90 and Willmott agreement index of 0.94 , resulting in a performance index of 0.85 .
\end{abstract}

KEYWORDS: growing degree-days, base temperature, thermal requirement, Fourier series.

\section{MODELAGEM ESPAÇOTEMPORAL DA DURAÇÃO DO CICLO DO ALGODOEIRO PARA O ESTADO DE GOIÁS}

RESUMO: O objetivo deste trabalho foi desenvolver e validar um modelo matemático para estimar a duração do ciclo do algodoeiro (Gossypium hirsutum L. r. latifolium hutch) no Estado de Goiás, aplicando o método de graus-dia (GD) e considerando sua variação espaçotemporal. O modelo foi desenvolvido por meio de combinação linear entre altitude, latitude, longitude e a variação temporal, representada pela série trigonométrica incompleta de Fourier. Os parâmetros do modelo foram ajustados, por meio de regressão linear múltipla, aos dados de GD para o algodoeiro, acumulados entre $15^{\circ} \mathrm{C}$ e $40^{\circ} \mathrm{C}$. Os dados utilizados de temperaturas máxima e mínima foram obtidos de séries históricas de 21 estações meteorológicas, com períodos de observações variando entre 8 e 24 anos. A validação do modelo foi feita comparando-se a duração da fase entre a emergência e $90 \%$ de capulhos abertos de cultivares de algodoeiros plantados em lavouras comerciais. O coeficiente de determinação resultante do ajuste do modelo aos dados observados foi de 0,84 . Os resultados dessa comparação mostraram que o modelo proposto teve um desempenho muito bom, conforme indicado pelo coeficiente de correlação de Pearson de 0,90 e o índice de concordância de Willmott de 0,94, que resultaram em um índice de desempenho de 0,85.

PALAVRAS-CHAVE: graus-dia, temperatura base, requerimento térmico, série de Fourier.

\footnotetext{
${ }^{1}$ Eng ${ }^{\circ}$ Agrícola, Doutor em Agronomia, Embrapa Cerrados, jor_ge.antonini@cpac.embrapa.br.

${ }^{2}$ Eng ${ }^{\mathrm{O}}$ Agrônomo, Doutor, Embrapa Cerrados.

${ }^{3}$ Eng ${ }^{\mathrm{O}}$ Agrícola, Professor, Doutor em Engenharia Agrícola, Universidade Federal de Goiás.

${ }^{4}$ Geólogo, Doutor, Embrapa Cerrados.

Recebido pelo Conselho Editorial em: 17-6-2009

Aprovado pelo Conselho Editorial em: 2-5-2011
} 


\section{INTRODUCTION}

Cotton cultivation in the Brazilian state of Goiás faces high production costs and low market prices. In this context of risk, the equilibrium point has been constant yield increases (ALMEIDA, 2006; IBGE, 2008). However, for the cotton crop be able to express its full potential in terms of yield and fiber quality, sowing has to occur when the soil is sufficiently moist for good germination, seeking also to overlap the period of highest water requirement of the crop with the months with the period of highest water supply, and the dry period with boll opening and harvest (AMORIM NETO et al., 2001). To define the best time to sow, climatic risk zoning has been used, in which soil water availability, the plant's agronomical traits, and climate are taken into consideration in order to minimize the negative impact of climate (SILVA et al., 2007).

To establish climatic risk zoning, it is necessary to know, among other parameters, the duration of the crop cycle, which depends basically on the cultivar, soil fertility, pest incidence, and meteorological conditions (AZEVEDO et al., 1999). The first three factors are controllable; whereas the latter depends on the environment, especially air temperature (ROSOLEM, 2001). When the relation between temperature and plant development rate is linear, the method of growing degree-days (GD) has been used to relate crop development with local thermal conditions (PRELA et al., 2006). The GD concept is based on the premise that there are two temperature thresholds, a minimum $\left(\mathrm{T}_{\mathrm{b}}\right)$ and a maximum $\left(\mathrm{T}_{\mathrm{B}}\right)$, between which the plant develops normally. In the case of cotton, it is assumed that $\mathrm{T}_{\mathrm{b}}$ equals to $15^{\circ} \mathrm{C}$, and $\mathrm{T}_{\mathrm{B}}$ equals to $40^{\circ} \mathrm{C}$, assuming that below and above these values, respectively, the development of the cotton plant is zero or very low (VIATOR et al., 2005; LIMA \& SILVA, 2008; BELTRÃO et al., 2007).

The GD accumulation required by the plant is considered to be a characteristic thermal constant of the cultivar, and independent of period and place of cultivation (PEREIRA et al., 2002). The understanding of the thermal constant in the respective phonological phases of the cotton crop is fundamental to foresee the duration of the cycle in different environments, in order to allow scheduling the best sowing period (CALVE et al., 2005). American cultivars accumulate between $1,575^{\circ} \mathrm{C}$ and $1,675^{\circ} \mathrm{C}$ for $\mathrm{T}_{\mathrm{b}}=15^{\circ} \mathrm{C}$ during the phase encompassing the emergence and the opening of the first boll (OOSTERHUIS, 1999). In Brazil, for the same conditions, the cultivars ITA 90 and Antares require $1,287^{\circ} \mathrm{C}$ (ROSOLEM, 2001); and the cultivars IAC 22, CNPA Acala 1 and CNPA Precoce 2 require 1,364; 1,539 and $1,085^{\circ} \mathrm{C}$ for $\mathrm{T}_{\mathrm{b}}=13{ }^{\circ} \mathrm{C}, 12{ }^{\circ} \mathrm{C}$, and $15^{\circ} \mathrm{C}$, respectively (BOLONHEZI, 2000); and upland cotton usually requires an accumulation of $1,650{ }^{\circ} \mathrm{C}$ for $\mathrm{T}_{\mathrm{b}}=12.7^{\circ} \mathrm{C}$ (GONÇALVES et al., 1999).

GD quantification is carried out from daily data of the minimum and maximum temperatures registered in meteorological stations. However, data are not always available from all sites for bioclimatic characterization of a region. This scarcity of information may be overcome by estimating GD by means of mathematical models based on historical series of climate data, similarly to what has been done to estimate air temperature (CARVALHO et al., 2005; STAHL et al., 2006; CARGNELUTTI FILHO et al. 2006) as a function of geographical coordinates and a certain time period. BURIOL \& ESTEFANEL (1976) estimated the sum of monthly and annual GD at the state of Rio Grande do Sul as a function of the altitude, latitude, longitude, using $\mathrm{T}_{\mathrm{b}}$ of $0{ }^{\circ} \mathrm{C}$, $5{ }^{\circ} \mathrm{C}, 10^{\circ} \mathrm{C}, 15^{\circ} \mathrm{C}$ and $20^{\circ} \mathrm{C}$, and obtained coefficients of determination ranging between 0.92 and 0.97 , depending on the month and the $\mathrm{T}_{\mathrm{b}}$ applied. PEDRO JÚNIOR et al. (1977) correlated GD with altitude and latitude by means of multiple linear regressions, and obtained coefficients of determination varying between 0.81 and 0.88 , depending on the month analyzed. Despite the relevant contribution of these reports, GD modeling has been carried out considering the spatial and temporal variables separately, and using only monthly or annually scale.

This work aimed at developing and validating a mathematical model to estimate cycle duration of cotton crop in Goiás state, applying the method of growing degree-days in a daily scale, considering together time-space variation. 


\section{MATERIAL AND METHODS}

This study at the state of Goiás, in an area delimited between latitudes $12.0000^{\circ} \mathrm{S}$ and $19.76222^{\circ} \mathrm{S}$, and longitudes $45.75889^{\circ} \mathrm{W}$ and $53.50000^{\circ} \mathrm{W}$, with climatic data obtained in 21 meteorological stations distributed in different municipalities and at several altitudes (Table 1).

From the mean daily air temperature data obtained from the historical series analyzed, values of degree-days available were calculated for cotton, corresponding to each day of the year, by means of the following equation (OOSTERHUIS, 1999):

$$
\mathrm{GDo}_{\mathrm{ij}}=0.5\left(\operatorname{Tmax}_{\mathrm{ij}}+\mathrm{Tmin}_{\mathrm{ij}}\right)-\mathrm{T}_{\mathrm{b}}
$$

where,

$\mathrm{GDo}_{\mathrm{ij}}$ - degree-day value observed on day i of year $\mathrm{j},{ }^{\circ} \mathrm{C}$;

Tmax $_{i j}$ - observed value of maximum air temperature on day i of year $\mathrm{j},{ }^{\circ} \mathrm{C}$;

$\mathrm{Tmin}_{\mathrm{ij}}$ - observed value of minimum air temperature on day $\mathrm{i}$ of year $\mathrm{j},{ }^{\circ} \mathrm{C}$, and

$\mathrm{T}_{\mathrm{b}}$ - low temperature threshold of the crop, ${ }^{\circ} \mathrm{C}$.

TABLE 1. Geographical location of the meteorological stations and observation period of the temperature data.

\begin{tabular}{clcccc}
\hline Order & Municipalities & $\begin{array}{c}\text { Altitude } \\
(\mathrm{m})\end{array}$ & $\begin{array}{c}\text { Latitude } \\
\text { South }\left(^{\mathrm{o}}\right)\end{array}$ & $\begin{array}{c}\text { Longitude } \\
\text { West }\left(^{\circ}\right)\end{array}$ & $\begin{array}{c}\text { Period } \\
\text { (year) }\end{array}$ \\
\hline 1 & Aragarças-GO $^{(1)}$ & 311 & 15,900 & 52,230 & $1985-2000$ \\
2 & Brasília-DF $^{(1)}$ & 1,161 & 15,789 & 47,926 & $1985-2000$ \\
3 & Britânia-GO $^{(2)}$ & 284 & 15,429 & 51,220 & $2000-2007$ \\
4 & Caldas Novas-GO $^{(2)}$ & 706 & 17,726 & 48,616 & $2000-2007$ \\
5 & Catalão-GO $^{(1)}$ & 886 & 18,158 & 47,926 & $2000-2007$ \\
6 & Ceres-GO $^{(2)}$ & 589 & 15,308 & 49,598 & $2000-2007$ \\
7 & Formosa-GO $^{(1)}$ & 899 & 15,530 & 47,330 & $1985-2000$ \\
8 & Goianésia-GO $^{(1)}$ & 665 & 15,220 & 48,990 & $1985-2000$ \\
9 & Goiânia-GO $^{(1)}$ & 722 & 16,643 & 49,222 & $1985-2000$ \\
10 & Goiás-GO $^{(1)}$ & 512 & 15,939 & 50,141 & $1985-2000$ \\
11 & Goiatuba-GO $^{(2)}$ & 774 & 18,013 & 49,357 & $2000-2007$ \\
12 & Ipameri-GO $^{(1)}$ & 743 & 17,717 & 48,167 & $1985-2000$ \\
13 & Iporá-GO $^{(2)}$ & 596 & 16,442 & 51,118 & $2000-2007$ \\
14 & Itaberaí-GO $^{(2)}$ & 701 & 16,020 & 49,810 & $2000-2007$ \\
15 & Itumbiara-GO $^{(2)}$ & 455 & 18,420 & 49,218 & $2000-2007$ \\
16 & Jataí-GO $^{(1)}$ & 669 & 17,924 & 51,718 & $1985-2000$ \\
17 & Palmeiras de Goiás-GO $^{(2)}$ & 621 & 16,810 & 49,911 & $2000-2007$ \\
18 & Porangatu-GO $^{(2)}$ & 368 & 13,374 & 49,128 & $2000-2007$ \\
19 & Posse-GO $^{(1)}$ & 824 & 14,089 & 46,366 & $1985-2000$ \\
20 & Santa Helena de Goiás-GO $^{(2)}$ & 590 & 17,839 & 50,576 & $2000-2007$ \\
21 & Santo Antônio de Goiás-GO $^{(3)}$ & 829 & 16,500 & 49,282 & $1983-2006$ \\
\hline (1)Instituto Nacional de Meteorologia - INMET; ${ }^{(2)}$ Sistema de Meteorologia e Hidrologia do Estado de Goiás - SIMEHGO; \\
${ }^{(3)}$ Centro Nacional de Pesquisa de Arroze Feijão-CNPAF. & & & &
\end{tabular}

To calculate the $\mathrm{GDo}_{\mathrm{ij}}$ available for cotton, a $\mathrm{T}_{\mathrm{b}}$ of $15{ }^{\circ} \mathrm{C}$ and a $\mathrm{T}_{\mathrm{B}}$ of $40{ }^{\circ} \mathrm{C}$ were assumed (BELTRÃO et al., 2007). These values were established as respective limits of minimum and maximum air temperatures, every time temperatures registered at the meteorological stations were below or above these limits.

To model the estimation of degree-days (eq. 2) as a function of time-space, the mean degreeday values $\left(\mathrm{GDom}_{\mathrm{js}}\right)$ observed each day of the year during the period registered in the historical series analyzed were adopted as a dependent variable. Independent variables were altitude (Alt), latitude (Lat), longitude (Long) and the sequence of the days of the year (i), following the procedure 
adopted by ANTONINI et al. (2009). The first three independent variables are responsible for the spatial variation of degree-days values, whereas the last variable describes the temporal variation. Since the temporal variation is a periodical phenomenon, it can be represented by the Fourier's trigonometric series (CARVALHO et al., 2005) and, according to QUEIROZ et al. (2001), it is possible to be adjusted by using only the first three harmonics of this series. GD modeling was conducted with the daily scale as follows:

$$
\text { GDom }_{\mathrm{is}}=\mathrm{C}_{0}+\mathrm{C}_{1} \text { Alt }+\mathrm{C}_{2} \text { Lat }+\mathrm{C}_{3} \text { Long }+\sum_{\mathrm{n}=1}^{3}\left[\alpha_{\mathrm{n}} \cos (\mathrm{nwi})+\beta_{\mathrm{n}} \operatorname{sen}(\mathrm{nwi})\right]
$$

where,

$\mathrm{i}$ - $i$ th day of the year, ranging from 1 to 365 days;

$\mathrm{s}$ - sth historical series, ranging from 1 to 21 series;

$\mathrm{C}_{0}$ - linear coefficient;

$\mathrm{C}_{1}, \mathrm{C}_{2}$ e $\mathrm{C}_{3}$ - angular coefficients of the spatial variables;

Alt - local altitude, m;

Lat - local latitude in positive values (decimal degrees);

Long - local longitude in positive values (decimal degrees);

$\alpha_{\mathrm{n}}$ e $\beta_{\mathrm{n}}$ - coefficients of the terms in the Fourier's trigonometric series;

$\mathrm{n}$ - number of harmonics of the Fourier's trigonometric series, and

$\mathrm{w}$ - angular frequency, being $2 \pi / 365$.

The angular coefficients $\alpha_{\mathrm{n}}$ e $\beta_{\mathrm{n}}$, called harmonic amplitude, represent in this modeling when $\mathrm{n}$ equals to one, two and three, respectively, to the daily degree-day amplitude of the year, semester and quarter.

To adjust the proposed model, it was utilized mean values of daily degree-days available for cotton crop of non-standardized periods with at least eight years of observation. From $\mathrm{GDo}_{\mathrm{ij}}$ daily values, GDom $_{\text {is }}$ values of the historical series analyzed were calculated, considering the days of the year as a sequence from one to 365 days and using the following equation:

$$
\mathrm{GDom}_{\mathrm{is}}=\sum_{\mathrm{j}=1}^{\mathrm{p}_{\mathrm{o}}}\left(\mathrm{GDo}_{\mathrm{ij}} / \mathrm{p}_{\mathrm{o}}\right)
$$

where,

$\mathrm{j}$ - $j$ th year of observation, and

$\mathrm{p}_{\mathrm{o}}$ - number of years of data observation of the historical series in each station.

GDom $_{\text {is }}\left({ }^{\circ} \mathrm{C}\right)$ values, totaling 7,665 variables, together with values of latitude, longitude and altitude and components of the Fourier's trigonometric series developed for the first three harmonics: $\cos (w i), \cos (2 w i), \cos (3 w i), \operatorname{sen}(w i), \operatorname{sen}(2 w i)$ and $\operatorname{sen}(3 w i)$ formed a matrix with 7,665 rows and ten columns. Statistical computation resources in Excel ${ }^{\mathrm{TM}}$ were used to determine the model coefficients through analysis of multiple linear regression. The degree of fit of the model was evaluated by the coefficient of determination and verification of the significance of the coefficients by the Student's $t$-test at $5 \%$ of probability of error.

To obtain the sum of degree-days required in a certain phase ( $\left.\mathrm{SGD}_{\text {Ini-Fin }}\right)$, comprised between two developmental stages of the crop, an adjusted model was used:

$$
\mathrm{SGD}_{\text {Ini-Fin }}=\sum_{\mathrm{i}=\text { Ini }}^{\text {Fin }} \mathrm{GD}_{\mathrm{i}}
$$

where,

Ini - corresponds to the day of the year of the characterization of a given developmental stage of the crop, and

Fin - corresponds to the day of the following characterization of the considered stage. 
Considering that the adjusted eq.(2) is continuous and periodical in the interval between 1 and 365 days, it repeats at the start of the following year, in which counting of days can continue without forfeit of continuity, from the $366^{\text {th }}$ day on. Thus, the $\mathrm{GD}_{\mathrm{i}}$ function can be used to estimate crop cycles that continue from one year to another. The summation indicated by eq.(4) can be carried out as an integral, as follows:

$$
\mathrm{SGD}_{\text {Ini-Fin }}=\int_{\mathrm{i}=\text { Ini }}^{\mathrm{Fin}} \mathrm{GD}_{\mathrm{i}} d i \quad \text { para } \mathrm{GD}_{\mathrm{i}} \geq 0
$$

Therefore, knowing the spatial variables (Alt, Lat, and Long) of the crop location, the date of the stage corresponding to the value Ini and the quantity of degree-days required in the phase considered $\mathrm{SGD}_{\text {Ini-Fin }}$, it is possible to calculate the Fin value, using any resource of non-linear optimization, such as the routine "Solver" in Excel ${ }^{\mathrm{TM}}$ used herein. The difference Fin-Ini corresponds to the duration of the phase considered.

The cultivars of cotton used in the validation of the proposed model were: Delta Opal, Nu Opal, Fibermax 993, FMT 701 and BRS 269 Buriti (Table 2), being the first four ones cultivated in commercial crops during the production years of 2006/2007 and 2007/2008 in different municipalities in Goiás state and the last cultivar was analyzed in an experimental location during the year of 2006/2007. Both cropping systems, commercial and experimental, were carried out following proper agronomic practices and did not suffer any severe water deficit during their development. The observation and determination of cycle duration and the requirement of degreedays were carried out during the phase between the emergences and when $90 \%$ of the bolls were open, Ini and Fin, respectively. In the case of commercial crops, since a detailed study of crop phenology was not carried out, it was established that $90 \%$ of open bolls occurred twenty days before harvest.

These cultivars were grouped into two classes, according with the duration of their developmental cycle: medium (Delta Opal e Nu Opal) and late (BRS 269 Buriti, Fibermax 993 and FMT 701). The sum of degree-days in each group for the considered phase was established with the mean of three repetitions of calculated values for the cultivars with a group. In the medium-cycle group, repetitions with calculated values of degree-day requirement were carried out: Delta Opal, at the California II farm, in Ipameri; $\mathrm{Nu}$ Opal at the Bom Jesus farms, in Morrinhos, and at São Sebastião, in Montividio. For the late-cycle group, repetitions were made with values of degree-day requirements of the cultivars: Fibermax 993 at the Gávea farm, in Ipameri; FMT 701 at the Pai Manoel farm, in Rio Verde; and BRS 269 - Buriti at the experimental area of Fundação-GO, in Santa Helena.

The mean degree-days required for the medium- and late-cycle groups were $1,519 \pm 35^{\circ} \mathrm{C}$ and $1,609 \pm 69^{\circ} \mathrm{C}$, respectively, being statistically significant at the probability level of $4.1 \%$. The choice of the cropping areas took into account that the municipalities should be located where data of the mean daily temperatures were available. 
TABLE 2. Cotton cultivars conducted in commercial crop fields and the respective duration of cycle in the period from cotton germination to the stage when $90 \%$ of bolls were open in the State of Goiás, Brazil.

\begin{tabular}{|c|c|c|c|c|c|}
\hline Municipality/Farm & Cultivar & $\begin{array}{l}\text { Altitude } \\
(\mathrm{m})\end{array}$ & $\begin{array}{c}\text { Latitude } \\
\left({ }^{\circ}\right)\end{array}$ & $\begin{array}{c}\text { Longitude } \\
\left({ }^{\circ}\right)\end{array}$ & $\begin{array}{l}\text { Cycle } \\
\text { (days) }\end{array}$ \\
\hline Palmeiras de Goiás/Santana & Delta Opal & 670 & 16.8852 & 49.8909 & 155 \\
\hline Ipameri/California II & Delta Opal $^{(1)}$ & 835 & 17.7329 & 48.2103 & 169 \\
\hline Lusitania/Macaé & Delta Opal & 960 & 16.3507 & 47.6797 & 188 \\
\hline Mineiros/Rio Grande & Delta Opal & 847 & 17.8551 & 53.0374 & 160 \\
\hline Chapadão do Céu/Lucas & Delta Opal & 780 & 18.3907 & 52.5263 & 171 \\
\hline Acreuna/Mutuca & $\mathrm{Nu}$ Opal & 553 & 17.4855 & 50.3900 & 146 \\
\hline Montividiu/São Sebastião & $\mathrm{Nu} O \mathrm{Opal}^{(1)}$ & 830 & 17.2886 & 51.2580 & 183 \\
\hline Campo Alegre de Goiás/Paineras & $\mathrm{Nu}$ Opal & 960 & 17.2967 & 47.8418 & 190 \\
\hline Campo Alegre de Goiás/Entre Rios & $\mathrm{Nu} O \mathrm{Opal}$ & 800 & 17.6321 & 47.6513 & 176 \\
\hline Morrinhos/Bom Jardim & $\mathrm{Nu} \mathrm{Opal}^{(1)}$ & 742 & 17.5935 & 49.0481 & 170 \\
\hline Piracanjuba/Nossa Senhora & $\mathrm{Nu}$ Opal & 677 & 17.5417 & 48.9813 & 165 \\
\hline Inaciolândia/Faceira & $\mathrm{Nu} O \mathrm{Opal}$ & 480 & 18.5469 & 49.8638 & 149 \\
\hline Parauna/São Geraldo & Fibermax 933 & 777 & 16.9611 & 51.0141 & 172 \\
\hline Ipameri/Gávea & Fibermax $933^{(2)}$ & 956 & 17.3006 & 48.3169 & 185 \\
\hline Caiapônia/Nova & Fibermax 933 & 670 & 16.7601 & 51.7189 & 153 \\
\hline Ipameri/Santo Antônio & Fibermax 933 & 840 & 17.6816 & 48.2830 & 198 \\
\hline Silvânia/Cedro & Fibermax 933 & 908 & 16.4888 & 48.3754 & 183 \\
\hline Rio Verde/Pai Manoel & FMT $701^{(2)}$ & 860 & 17.7535 & 51.3000 & 189 \\
\hline Cristalina/Pamplona & FMT 701 & 970 & 16.2536 & 47.6789 & 200 \\
\hline Sta. Helena de Goiás/Fundação-GO & BRS 269-Buriti ${ }^{(2)}$ & 569 & 17.8362 & 50.5779 & 157 \\
\hline
\end{tabular}

${ }^{(1)}$ Cultivars of medium cycle used to determine the summation of degree-days between emergence and $90 \%$ of bolls open;

${ }^{(2)}$ Ditto for cultivars of late cycle.

To evaluate the performance of the model estimating the duration of the developmental cycle of cotton in the state of Goiás, the estimated values were correlated with observed data in the selected commercial crops. The quality of the estimation was evaluated statistically for precision, accuracy and performance. Precision was quantified by Pearson's correlation coefficient (r) and interpreted according to SANTOS (2007). Accuracy was quantified by Willmott's d concordance index, which varies from zero for no concordance, to one for perfect concordance (WILLMOTT, 1982). Performance was quantified by the $\mathrm{c}$ index, defined as a product between $\mathrm{r}$ and $\mathrm{d}$ (CAMARGO \& CAMARGO, 2000) and interpreted according to CAMARGO \& SENTELHA (1997).

\section{RESULTS AND DISCUSSION}

The model coefficients of degree-day estimation, $\mathrm{GD}_{\mathrm{i}}$, obtained by multiple linear regression analysis applied to cotton crops cultivated in the states of Goiás were: $\mathrm{C}_{0}=21.34268$; $\mathrm{C}_{1}=-0.00708 ; \quad \mathrm{C}_{2}=-0.14031 ; \mathrm{C}_{3}=-0.08713 ; \alpha_{1}=1.12030 ; \alpha_{2}=-0.96597 ; \alpha_{3}=0.11965 ;$ $\beta_{1}=-0.41280 ; \beta_{2}=0.17409 ; \beta_{3}=0.08571$. All coefficients were highly significant at the $5 \%$ level with $P<0.0001$. The determination coefficient of comparison between the values estimated by the model and the values calculated based on maximum and minimum temperatures of the historic series utilized was $84 \%$ (Figure 1), i.e., only $16 \%$ of the $\mathrm{GD}_{\mathrm{i}}$ variability was not explained by altitude, latitude, longitude and seasonality. Similar results were described by BURIOL \& ESTEFANEL (1976) when developing regression equations to estimate the annual and monthly GD sum for Rio Grande do Sul state by using different $T_{b}$ values and having as independent variables altitude, latitude, longitude, and a continental factor. They obtained determination coefficients varying between 0.92 and 0.97 as a depending on the month and $\mathrm{T}_{\mathrm{b}}$ used. PEDRO JÚNIOR et al. 
(1977) established monthly equations to estimate GD as a function of local altitude and latitude and obtained high coefficients of determination, with values ranging between 0.81 and 0.88 , depending on the month considered. By analyzing specially the coefficient $\mathrm{C}_{1}$ of altitude, one can infer that GD decreases $0.7^{\circ} \mathrm{C}$ for each $100 \mathrm{~m}$ elevation. This decrease is related to the decrease of mean air temperature with the increase of altitude, which theoretical average is $0.6{ }^{\circ} \mathrm{C}$ for every $100 \mathrm{~m}$ elevation (PEREIRA et al., 2002). In relation to the coefficient $\mathrm{C}_{2}$ of latitude, each unit increase corresponds to approximately $0.14{ }^{\circ} \mathrm{C}$ decrease in degree-days. This decrease in air temperature in relation to the latitude is due to a decrease in solar radiation with the increase of latitude, which is due to the increase of atmosphere thickness traversed by the sunrays in higher latitudes (SILVA, 2006). A decrease of $0.09{ }^{\circ} \mathrm{C}$ in degree-days per degree of increase in longitude was also observed.

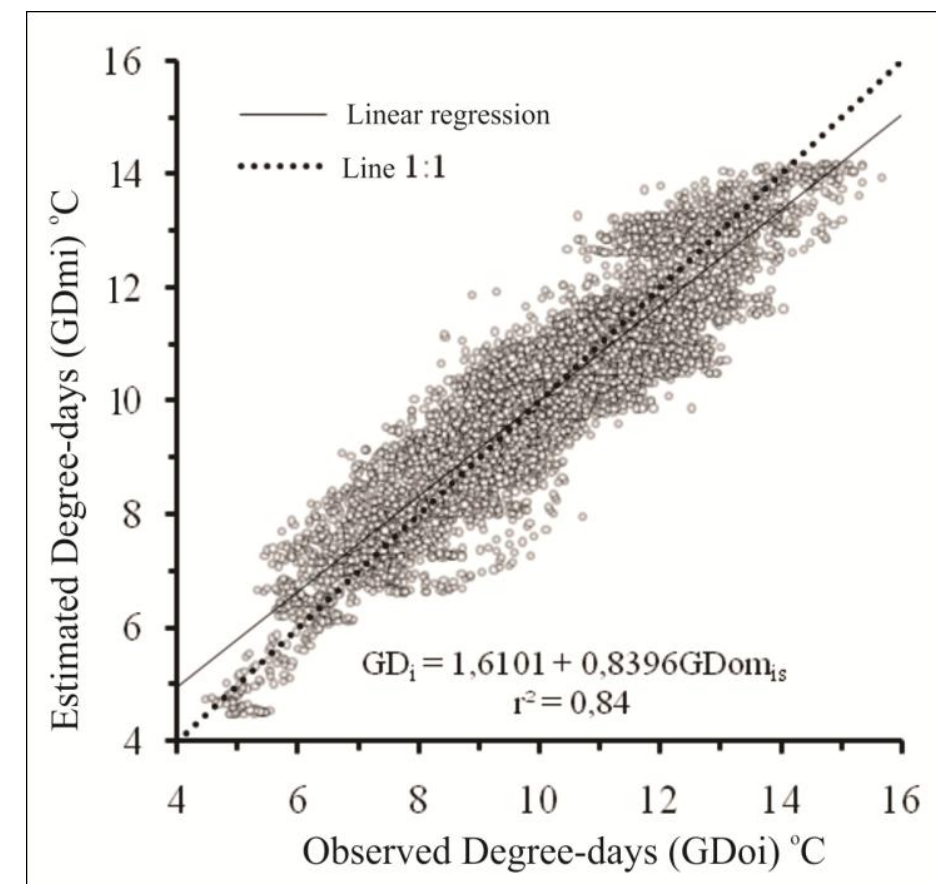

FIGURE 1. Comparison between observed $\left(\mathrm{GDo}_{\mathrm{i}}\right)$ and estimated $\left(\mathrm{GDm}_{\mathrm{i}}\right)$ growing degree-days and the corresponding determination coefficient $r^{2}$.

Figure 1 also shows that the regression curve presents an inclination in comparison to a curve $1: 1$, suggesting that the model under and overestimate the sum of degree-days for temperatures below and above $\sim 25^{\circ} \mathrm{C}$.

The values of required degree-days during the developmental phase between the emergence and $90 \%$ of bolls open, for the cultivars utilized in the validation of the proposed model were: $1,519{ }^{\circ} \mathrm{C} \pm 35^{\circ} \mathrm{C}$ for the medium-cycle group (Delta Opal and $\mathrm{Nu}$ Opal) and $1,609{ }^{\circ} \mathrm{C} \pm 69{ }^{\circ} \mathrm{C}$ for the late-cycle group (BRS 269 - Buriti, Fibermax 993 and FMT 701). It was not found reports in the literature related to requirements of degree-days specifically for this phase. However, these results are consistent when comparing values of degree-days obtained during different phases in other studies. ROSOLEM (2001) found that a requirement of $1,287^{\circ} \mathrm{C}$ for medium-cycle cultivars (CNPA ITA 90 and Antares) during the phase between emergence and the first open boll, and GONÇALVES et al. (1999) found a requirement of $1,650^{\circ} \mathrm{C}$ for cotton between the emergence and the final of the cycle, considering a total cumulative GD between $12,7^{\circ} \mathrm{C}$ and $37^{\circ} \mathrm{C}$. Given the scarcity of information about the requirement of degree-days for cotton during the different developmental phases of the crop, the results found in this study do not resolve all questions, but it does point out the need of research on this topic, as well as the need to standardize a method to determine the crop's temperature thresholds. 
The integration of equation 5 results in an analytical mathematical expression that allows obtaining the final duration of a given developmental phase of the crop. The result of this integration can be expressed as follows, considering already determined values of coefficients of the adjusted model:

$$
\begin{aligned}
S_{G D} \text { Ini-Fin }= & (\text { Fin }- \text { Ini })\left(C_{0}+C_{1} A l t+C_{2} \text { Lat }+C_{3} \text { Long }\right)+ \\
& \sum_{n=1}^{3}(1 / n w)\left\{\alpha_{n}[\operatorname{sen}(n w F i n)-\operatorname{sen}(n w I n i)]-\beta_{n}[\cos (n w F i n)-\cos (n w I n i)]\right\}
\end{aligned}
$$

By applying equation 6, it is possible to establish the value for the variable Fin, corresponding to the stage when $90 \%$ of open bolls, for a given sowing date and a certain location. It is noteworthy that, by establishing the mean daily temperature thresholds between 15 and $40{ }^{\circ} \mathrm{C}$, the integration of this model results automatically in an equation that accounts only for degree-days between this temperature intervals. Otherwise, if the mean daily air temperature were lower than $15{ }^{\circ} \mathrm{C}$ or higher than $40{ }^{\circ} \mathrm{C}$, the model (equation 6) would incorrectly consider thermal units below (negative) or above (positive) these limits.

Figure 2 shows the relation between the observed and the estimated values of cycle duration of the cultivars in commercial crops in Goiás state, during the developmental phase between the emergence stage and $90 \%$ of open bolls. The precision of the model estimation, assessed by the Pearson's correlation coefficient (r) was 0.90, which, according to SANTOS (2007), is a strong and positive correlation. Willmott's concordance index (d), which refers to the accuracy or approximation of the estimated date in relation to observed values, was 0.94, showing that the estimated values by the model are very close to the observed ones. An index value (c) of 0.85 also demonstrates a very good performance of the model (CAMARGO \& SENTELHA, 1997).

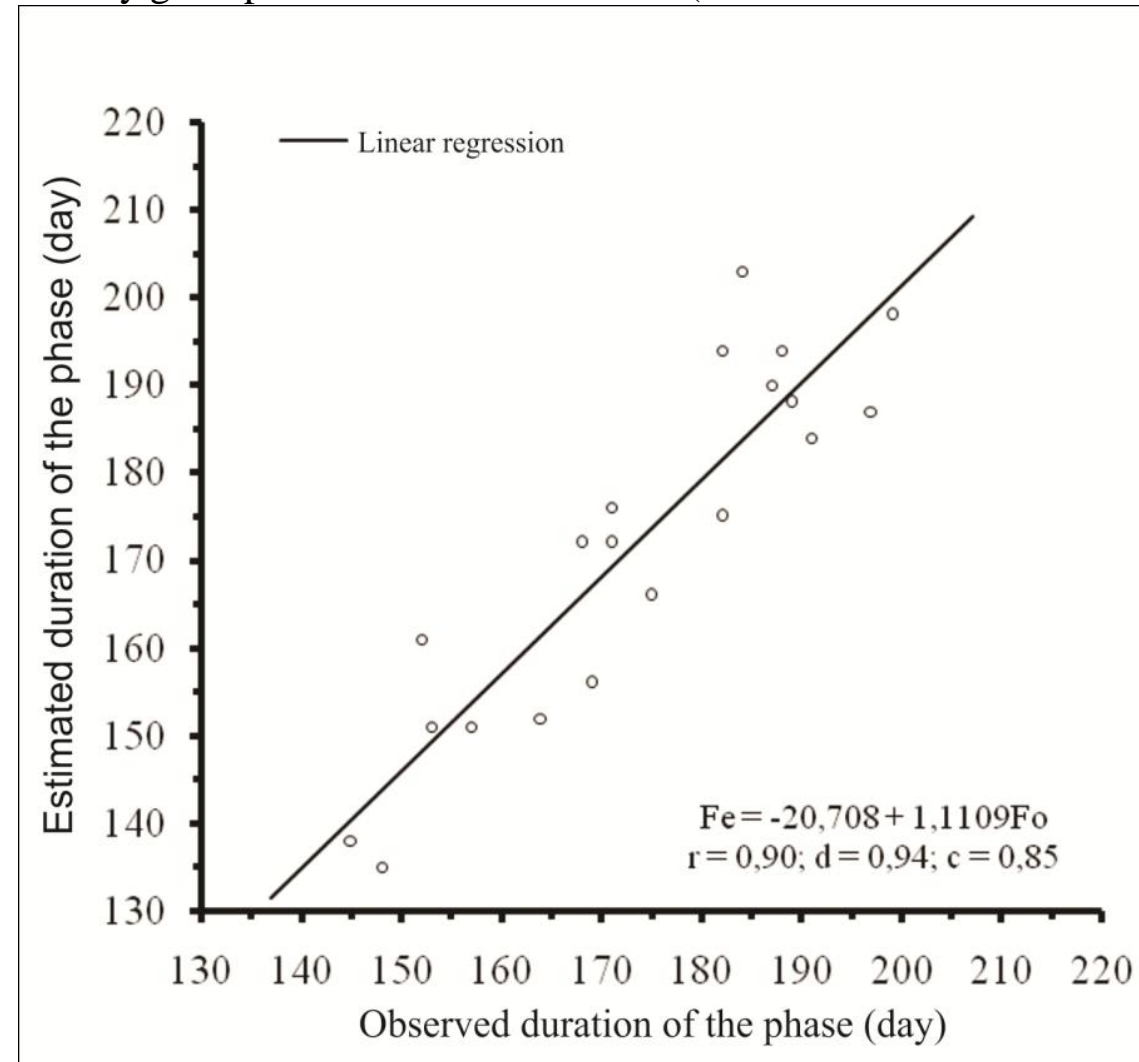

FIGURE 2. Comparison between observed (Fo) and estimated (Fe) values of duration of cotton crop developing phases from emergence to $90 \%$ of bolls open, and its corresponding statistical evaluation indices $(r=$ Pearson correlation coefficient; $d=$ Willmott agreement coefficient; and $\mathrm{c}=$ performance index). 


\section{CONCLUSIONS}

The proposed model:

- is well adjusted to observed annual degree-day values for cotton cultivars in the state of Goiás;

- estimates adequately the requirement of degree-days necessary to complete a determined developmental phase of cotton cultivars;

- shows optimal performance of estimation of cycle duration of cotton cultivars in commercial crops growing in the state of Goiás, which is well known for the need of degree-days given the developmental phase and sowing date considered .

\section{ACKNOWLEDGMENTS}

To the General Manager of Embrapa's Technology Transfer Office, José Roberto Rodrigues Peres, for enabling all necessary conditions to conduct this work; to Embrapa Cerrados, for logistic support; to Sistema de Meteorologia e Hidrologia do Estado de Goiás, for making data available; to Embrapa Cerrados researcher, Fernando Antônio Macena da Silva, for advising on data analysis; to the Embrapa Cerrados geographers, Heleno da Silva Bezerra and Balbino Antônio Evangelista, for support in the Environmental Biophysics lab.

\section{REFERENCES}

ALMEIDA, W. P. de. Conjuntura exige produção sustentável a custos baixos. Visão Agrícola, Piracicaba, n.6, p.32-34, jul./dez. 2006.

AMORIM NETO, M. da S.; ARAUJO, A.E. de; CARAMORI, P.H.; GONÇALVES, S.L.; WREGE, M.S.; LAZZAROTTO, C.; LAMAS, F.M.; SANS, L.M.A. Zoneamento agroecológico e definição da época de semeadura do algodoeiro no Brasil. Revista Brasileira de Agrometeorologia, Santa Maria, v.9, n.3, p.422-428, dez. 2001.

ANTONINI, J.C. dos A.; SILVA, E.M. da.; OLIVEIRA, L.F.C. de.; SANO, E.E. Modelo matemático para estimativa da temperatura média diária do ar no Estado de Goiás. Pesquisa Agropecuária Brasileira, Brasília, v.43, n.4, p.331-338, abr. 2009.

AZEVEDO, D.M.P. de; BELTRÃO, N.E. de M.; VIEIRA, D.J.; NOBREGA, L.B. da. Manejo cultural. In: BELTRÃO, N.E. de M. (Org.). O agronegócio do algodão no Brasil. Brasília: Embrapa Comunicação para Transferência de Tecnologia, 1999. v.2, cap.20, p.509-551.

BELTRÃO, N.E. de M.; FIDELES FILHO, J.; VALE, L.S. do. In: FREIRE, E.C. (Ed.). Algodão no cerrado do Brasil. Brasília: ABRAPA, 2007. cap.5, p.175-191.

BOLONHEZI, D. Época de semeadura do algodoeiro: características agronômicas, tecnológicas da fibra, determinação da temperatura base e graus-dia. 2000. 182 f. Dissertação (Mestrado em Produção Vegetal) - Faculdade de Ciências Agrárias e Veterinária, Universidade Estadual Paulista, Jaboticabal, 2000.

BURIOL, G. A.; ESTEFANEL, V. Estimativa das temperaturas efetivas do Estado do Rio Grande do Sul em função de fatores geográficos. Revista Centro de Ciências Rurais, Santa Maria, v.6, n.3, p.265-273,1976.

CALVE, L.; ALFONSI, R.R.; ASSAD, E.D. Planilhas de cálculo para estimativa do ciclo de culturas, a partir de graus-dia. In: CONGRESSO BRASILEIRO DE AGROMETEOROLOGIA, 14., 2005, Campinas. Anais... Campinas: SBA, 2005.

CAMARGO, A.P. de.; CAMARGO, M.B.P. de. Uma revisão analítica da evapotranspiração potencial. Bragantia, Campinas, v.59, n.2, p.125-137, 2000.

CAMARGO, A.P.; SENTELHAS, P.C. Avaliação de desempenho de diferentes métodos de estimativa da evapotranspiração potencial no Estado de São Paulo, Brasil. Revista Brasileira de Agrometeorologia, Santa Maria, v.5, n.1, p.89-97, 1997. 
CARGNELUTTI FILHO, A.; MALUF, J.R.T.; MATZANAUER, R.; STOLZ, A.P. Altitude e coordenadas geográficas na estimativa da temperatura mínima média decendial do ar no Estado do Rio Grande do Sul. Pesquisa Agropecuária Brasileira, Brasília, v.41, n.6, p.893-901, 2006.

CARVALHO, L.G. de; SEDIYAMA, G.C.; CECON, P.R.; ALVES, H.M.R. Aplicação da análise harmônica por série de Fourier para a previsão de produtividade da cultura do café no Estado de Minas Gerais. Engenharia Agrícola, Jaboticabal, v.25, n.3, p.732-741, 2005.

GONÇALVES, S.L.; CARAMORI, P.H.; WREGE, M.S.; OLIVEIRA, D.; MARUR, C. J.; ALMEIDA, W.P.; PIRES, J.R.; YAMAOKA, R.S.; ABUCARUB NETO, M.; BORROZINO, E. Regionalização e época de semeadura do algodão no Estado do Paraná. In: CONGRESSO BRASILEIRO DO ALGODÃO, 2., 1999, Ribeirão Preto. Anais... Campina Grande: EMBRAPACNPA, 1999. p.15-17.

IBGE. Sistema IBGE de Recuperação Automática - SIDRA: Agropecuária: Produção Agrícola Municipal: área colhida - Tabela 1612- Quantidade produzida, valor da produção, área plantada e área colhida da lavoura temporária: lavoura temporária = algodão herbáceo (em caroço). Disponível em: <http://www.sidra.ibge.gov.br/bda/tabela/listabl.asp? $\mathrm{z}=\mathrm{t} \& \mathrm{o}=1 \& \mathrm{i}=\mathrm{P} \& \mathrm{e}=1 \& \mathrm{c}=1612>$. Acesso em: 4 dez. 2008.

LIMA, E.D.; SILVA, E.L. da. Temperatura base, coeficiente de cultura e graus-dia para cafeeiro arábica em fase de implantação. Revista Brasileira de Engenharia Agrícola e Ambiental. Campina Grande, v.12, n.3, p.266-273, 2008.

OOSTERHUIS, D.M. Growth and development of cotton plant. In: CIA, E; FREIRE, E.C.; SANTOS, W.J. dos (Ed). Cultura do algodoeiro, Piracicaba: Potafos, 1999. p.35-55.

PEDRO JÚNIOR, M.J.; BRUNINI, O.; ALFONSI, R.R.; ANGELOCCI, L.R. Estimativa de grausdia em função da altitude e latitude para o Estado de São Paulo. Bragantia, Campinas, v.36, n.5, p.89-92, 1977.

PEREIRA, A.R.; ANGELOCCI, L.R.; SENTELHAS, P.C. Agrometeorologia: fundamentos e aplicações práticas. Guaíba: Agropecuária, 2002. 478 p.

PRELA, A.; GARCIA, B.I.L.; PEREIRA, A.R. Variação de graus-dia em Piracicaba (SP), em anos de El Niño e La Niña. Bragantia, Campinas, v.65, n.3, p.527-532, 2006.

QUEIROZ, E.F. de; SILVA, R.J.B. da; OLIVEIRA, M.C. de. Modelo de análise de regressão periódica da precipitação mensal, da bacia atlântico sudeste, no Estado do Paraná. Pesquisa Agropecuária Brasileira. Brasília, v.36, n.5, p.727-742, 2001.

ROSOLEM, C.A. Ecofisiologia e manejo da cultura do algodão. Piracicaba: POTAFOS, 2001. (Informações Agronômicas, 95).

SANTOS, C. Estatística descritiva: manual de auto-aprendizagem. Lisboa: Edições Silabo, 2007. $264 \mathrm{p}$.

SILVA, R.G. da. Predição da configuração de sombras de árvores em pastagens para bovinos. Engenharia Agrícola, Jaboticabal, v.26, n.1, p.268-281, 2006.

SILVA, J.C. da; HELDWEIN, A.B.; MARTINS, F.B.; STRECK, N.A.; GUSE, F.I. Risco de stresse térmico para o feijoeiro em Santa Maria, RS. Ciência Rural, Santa Maria, v.37, n.3, p.643-648, 2007.

STAHL, K.; MOORE, R.D.; FLOYER, I.A.; ASPLIN, M.G.; MECKENDRY, I.G. Comparison of approaches for spatial interpolation of daily air temperature in a large region with complex topography and highly variable station density. Agricultural and Forest Meteorology, Amsterdam, v.139, n.3-4, p. 224-236, 2006.

VIATOR, R.P.; NUTI, R.C.; EDNISTEN, K.L.; WELLS, R. Predicting cotton boll maturation period using degree days and other climatic factors. Agronomy Journal, v.97, p.494-499, 2005. 
WILLMOTT, C. J. Some comments on the evaluation of model performance. Bulletin of American Meteorological Society, Bosotn, v.63, n.11, p.1.309-1.313, 1982. 